\title{
INSECTICIDAL ACTIVITY OF PIPER GUINEENSE (SCHUMACH AND THONN) SEED OIL AGAINST CALLOSOBRUCHUS MACULATUS (F.) (COLEOPTERA: CHRYSOMELIDAE) IN STORED COWPEA SEEDS
}

\author{
Chukwunonso O. Nzelu ${ }^{* 1+}{ }^{凶}$, Kingsley C. Emeasor ${ }^{2}$, Nnaemeka J. Okonkwo 1,3 \\ ${ }^{* 1}$ Department of Parasitology and Entomology, Nnamdi Azikiwe University, Awka, Anambra State, \\ Nigeria \\ † Snyder Institute for Chronic Diseases, University of Calgary, Canada \\ 2 Department of Plant Health Management, Michael Okpara University of Agriculture, Umudike, \\ Abia State, Nigeria \\ ${ }^{3}$ Department of Crop Science and Horticulture, Nnamdi Azikiwe University, Awka, Anambra State, \\ Nigeria
}

DOI: https://doi.org/10.29121/granthaalayah.v8.i8.2020.875

Article Type: Research Article

Article Citation: Chukwunonso 0. Nzelu, Kingsley C. Emeasor, and Nnaemeka J. Okonkwo. (2020). INSECTICIDAL ACTIVITY OF PIPER GUINEENSE (SCHUMACH AND THONN) SEED OIL AGAINST CALLOSOBRUCHUS MACULATUS

(F.) (COLEOPTERA:

CHRYSOMELIDAE) IN STORED COWPEA SEEDS. International Journal of Research GRANTHAALAYAH, 8(8), 262-270. https://doi.org/10.29121/granthaa layah.v8.i8.2020.875

Received Date: 27 July 2020

Accepted Date: 31 August 2020

Keywords:

Bruchid

Pest Control

Plant-Derived Insecticides

Seed Oil

Stored Cowpea

\section{ABSTRACT}

Post-harvest losses due to insect pest infestation in storage constitute a challenge to sustainable food security and economic losses to farmers throughout the world. Use of synthetic chemicals have been the most effective means of reducing losses in storage. Unfortunately, these toxicants have adverse effects in humans and the environment. There is renewed search for safer plant products as alternatives. In this study, we assessed the potential use of Piper guineense seed oil in the control of cowpea bruchid, Callosobruchus maculatus (F.) infestation on stored cowpea seeds. Adult mortality, oviposition rate, F1 progeny emergence, cowpea seed damage and seed germinability were the indices considered in the assessment under laboratory conditions. The setup of the experiment was completely randomized design (CRD). Statistical analysis of the data was by analysis of variance (ANOVA). Adult C. maculatus mortality was dose-dependent with higher dosages inducing $100 \%$ mortality. The number of eggs laid on the treated seeds were significantly $(\mathrm{P}<0.001)$ reduced. Progeny emergence and feeding damage were completely inhibited at higher dosages. The seed oil has no adverse effect on cowpea seed viability. The results indicated that P. guineense seed oil has protectant potential against insect pest damage in storage and a good alternative to synthetic insecticides in the control of insect pest of stored products. 
Insecticidal Activity of Piper Guineense (Schumach And Thonn) Seed Oil Against Callosobruchus Maculatus (F.) (Coleoptera: Chrysomelidae) in Stored Cowpea Seeds

\section{INTRODUCTION}

Cowpea, Vigna unguiculata (L. Walp), is an annual crop in the family Fabaceae, grown successfully in extreme environments for its edible seeds and pods. The seeds are important food crop, high in protein content and source of revenue in tropical countries (Langyintuo et al. 2003; Adedire et al. 2011).

Storage insect pests are responsible for substantial damage in stored seeds, such as dry weight losses, reduced nutritional qualities, seed viability reduction and low market value. The extent of losses vary according to insect species. Callosobruchus maculatus (Fabricius) is a principal insect pest of stored cowpea seeds and can cause significant reduction in quality and quantity of seeds within 3-5 months of storage (IIeke et al. 2012). The insect is a cosmopolitan field-to-store pest as its infestation of cowpea often begins in the field while the mature pods dry (Murdock et al. 2003) and multiplies very rapidly in storage where it causes very high losses (Murdock et al. 2003; Ojo et al. 2013). Losses are mainly due to the consumption of cowpea seed cotyledons by larvae, resulting in reduced seed weight, increased seed perforation and decreased seed germination (Deshpande et al. 2011). Effective control measure is of paramount importance in order to avert adverse consequences due to insect pests damage to stored products and ensure steady food supply for the teeming world population.

Synthetic insecticides have been the major means of controlling insect pests largely due to their quick action and long lasting effect. However, apart from their high cost, there is growing concern for the use of synthetic insecticides because of some associated risks, such as environmental persistence, decimation of beneficial fauna, carcinogenic effect, insect resistance and other health problems (Ileke et al. 2012). These problems associated with the use of synthetic insecticides have necessitated the search for safer, cost-effective, readily available and biodegradable alternative insecticides. The use of plant materials with insecticidal properties will be of immense help to resource poor small-scale farmers since they are locally available, biodegradable, safe and cost effective (Echo et al. 2012; Shiberu 2013; Nzelu and Okonkwo 2016). Plant products such as powders, ashes and oils with insecticidal, anti-feedant and repellent properties have been identified and shown to be useful in the control of various insect pests (Raja et al. 2001; IIeke et al. 2012; Jayakumar 2010; Emeasor et al. 2017).

Piper guineense (Schumach and Thonn), the West African Black pepper, is a climbing perennial plant of the family Piperaceae. The edible seeds contain piperine, resins, alkaloids, tannins, saponins, terpenes, flavonoids, steroids, phenols and essential oils (Nwankwo et al. 2014; Besong et al. 2016; Ukpai et al. 2017). The seed oil is commonly used as aromatic in the beverage and pharmaceutical industries (Rehn and Espig 1991). The pungency of the black pepper is due to the presence of 5-8\% piperine (Besong et al. 2016). Piper guineense is also known to have antioxidant, anticonvulsant, antibacterial, anti-inflammatory, hepatoprotective, fertility, larvicidal and aphrodisiac properties (Echo et al. 2012; Okoye and Ebeledike 2013; Nwankwo et al. 2014; Memudu et al. 2015; Besong et al. 2016; Ukpai et al. 2017). Some studies have shown the effectiveness of Piper guineense seed powder in the control of insect pests of some vegetable crops, catfish and stored grains (Fasakin and Aberejo 2002; Ibekwe et al. 2014; Ukpai et al. 2017; Benson et al. 2019). In this study, we sought to evaluate the efficacy of Piper guineense seed oil for the control of $C$. maculatus infestation on stored cowpea seeds.

\section{MATERIALS AND METHODS}

\subsection{INSECT CULTURE}

Cowpea seeds were obtained from the Eke Awka Market, Anambra State, Nigeria and taken to the laboratory. The infested seeds were placed in a plastic container and covered with muslin cloth which was held in place with rubber bands in order to allow sufficient air into the container, till the emergence of adults. Emerged $C$. maculatus adults of both sexes were transferred into another plastic container containing sterilized clean cowpea seeds and maintained at $28 \pm 2^{\circ} \mathrm{C}, 60 \pm 5 \%$ R.H. and light/dark $12: 12$ hour cycle as culture for subsequent use. The culture was kept undisturbed to produce enough progeny used for the experiments. 


\subsection{PREPARATION AND EXTRACTION OF SEED OIL FROM PIPER GUINEENSE SEEDS}

Dried seeds of Piper guineense were similarly procured from the same Eke Awka Market, Anambra State, Nigeria. The dried seeds were ground into fine powder using a stainless electric grinder and sieved (mesh size: $1 \mathrm{~mm}^{2}$ ). The oil extraction was carried out using n-hexane solvent. P. guineense seed powder of $250 \mathrm{~g}$ was weighed into a beaker and $400 \mathrm{ml}$ of $\mathrm{n}$-hexane added. The mixture was stirred, left on the bench for $6 \mathrm{~h}$ and subsequently, filtered using filter paper (Whatman No. 1). The powder was repeatedly washed and filtered using $200 \mathrm{ml}$ of $\mathrm{n}$-hexane for 3 times. The filtrate was then transferred into Soxhlet Extractor maintained at $68.7^{\circ} \mathrm{C}$ by means of a heating mantle for evaporation and collection of the n-hexane. Further, the oil extract was dried in an oven $\left(95-100^{\circ} \mathrm{C}\right)$ for $1 \mathrm{~h}$. The seed oil extract was stored in air-tight bottle and kept at room temperature. This served as stock solution.

\subsection{BIOASSAY}

\subsubsection{COWPEA SEEDS}

Experimental cowpea seeds were properly sieved and hand-picked to ensure that only wholly and uninfested seeds were used. The seeds were also sterilized in electric oven at $50^{\circ} \mathrm{C}$ for $4 \mathrm{~h}$ to disinfest them thoroughly and allowed to cool for $1 \mathrm{~h}$ before use. All bioassay tests were carried out under ambient laboratory conditions, similar to the insect culture; $28 \pm 2{ }^{\circ} \mathrm{C}$ and $60 \pm 5 \%$ R.H. and $12 \mathrm{~h}: 12 \mathrm{~h}$ light: dark regime.

\subsubsection{TOXICITY OF PIPER GUINEENSE SEEDS OIL ON ADULT CALLOSOBRUCHUS MACULATUS}

Twenty grammes $(20 \mathrm{~g})$ of the cowpea sample were weighed separately into sterilized $100 \mathrm{ml}$ plastic jars. Serial dilutions containing 200,400,600, 800 and $1000 \mu \mathrm{l}$ of the oil in acetone (Analytical grade), corresponding to 1, 2, 3, 4 , and $5 \%$ concentration, respectively, were prepared. The treated seeds were vigorously shaken to ensure proper coating of the seeds and kept for 1-2h to allow the acetone evaporate completely. Controls without oil treatment $(0 \%)$ were included. Subsequently, twenty freshly-emerged C. maculatus adults (1-2 days old) of both sexes were introduced into each jar which was covered with a muslin cloth and held firmly with a rubber band to allow aeration and prevent exit or entry of insects. Each treatment level was repeated four (4) times and arranged in a completely randomized design on a workbench in the laboratory. The experiment was observed daily for 3 consecutive days and the number of dead insects in each jar was counted every $24 \mathrm{~h}$ and recorded. Percent bruchid mortality was determined using the standard formula:

$$
\% \text { mortality }=\frac{\text { Number of dead insects }}{\text { Total number of insects }} \times 100
$$

\subsubsection{EFFECT OF PIPER GUINEENSE SEEDS OIL ON OVIPOSITION, $F_{1}$ ADULT EMERGENCE AND ASSESSMENT OF SEED DAMAGE}

At the end of the mortality record, all insects were removed. The number of eggs laid on treated seeds (Ts) and control seeds (Cs) were recorded and the average number was calculated per treatment. After the egg count, the experimental set up was left undisturbed till the emergence of $\mathrm{F}_{1}$ adults from day 30 post treatment. The number of $F_{1}$ adults from the control (AC) and treated seeds (At) were recorded. The percentage reduction (PR) in $F_{1}$ progeny was calculated as follows:

$$
\mathrm{PR}=[(\mathrm{Ac}-\mathrm{At}) / \mathrm{Ac}] \mathrm{X} 100
$$

The number of damaged cowpea seeds (seeds with characteristic emergence holes) in both treated and untreated sample and undamaged seeds were counted. The number of damaged seeds were expressed as a percentage of the total number of seeds in each jar. 


\subsubsection{SEED GERMINATION TEST AFTER TREATMENT}

Viability of the treated seeds was carried out at the end of experiment using sterile glass Petri dishes containing Whatman No.1 filter paper $(10.9 \mathrm{~cm}$ diameter). Ten randomly selected seeds from each treatment, including the control $(0 \%)$ were taken from each jar for germination test. The seeds were moistened daily $(10 \mathrm{ml}$ of distilled water). The set-up was exposed to light on the laboratory workbench. The number of seeds that germinated was recorded after four days and the percentage germination was subsequently determined according to the following formula:

\section{$\%$ seed germination $=\underline{\text { Number of germinated seeds }} \times 100$ Total number of seeds}

\subsection{STATISTICAL ANALYSIS}

For the toxicity test, data obtained were transformed to percentage. Abbot's formula was used to adjust for treatment mortality after applying mortality in control treatment (Abbott 1925). Data obtained from parameters were subjected to analysis of variance (ANOVA), using SPSS software package. Furthermore, the mean separation was carried out using the Least Significant Difference (LSD) at 5\% level of significance.

\section{RESULTS}

\subsection{ADULT CALLOSOBRUCHUS MACULATUS MORTALITY}

The bioactivity of the P. guineense seed oil against adult $C$. maculatus is presented in Table 1 . All dosages of the oil significantly $(\mathrm{P}<0.001)$ caused mortality to the beetle compared to the control, irrespective of dosage. There was dose-dependent mortality response by the insects in the treated seed, with oil treatments of $800 \mu \mathrm{l} / 20 \mathrm{~g}$ and above, inducing $100 \%$ mortalities of the bruchid within $72 \mathrm{~h}$.

Table 1: Effect of P. guineense seed oil on adult mortality of C. maculatus

\begin{tabular}{|c|c|}
\hline Dosage $(\mu \mathrm{l} / 20 \mathrm{~g})($ Concentration $\%)$ & $\%$ mortality \\
\hline Control $(0.0 \%)$ & $5.533 \pm 2.767 \mathrm{a}$ \\
\hline $200(1.0 \%)$ & $58.333 \pm 17.342 \mathrm{~b}$ \\
\hline $400(2.0 \%)$ & $72.233 \pm 18.375 \mathrm{c}$ \\
\hline $600(3.0 \%)$ & $89.600 \pm 10.400 \mathrm{~d}$ \\
\hline $800(4.0 \%)$ & $100.000 \pm 0.000 \mathrm{e}$ \\
\hline $1000(5.0 \%)$ & $100.000 \pm 0.000 \mathrm{e}$ \\
\hline
\end{tabular}

Means \pm SE followed by different letters are significantly different at the 0.05 level. Mortality was significant at $\mathrm{P}<0.001$ by Fisher's F-test.

SE: standard error.

\subsection{EFFECT OF THE SEED OIL ON OVIPOSITION, ADULT EMERGENCE AND SEED DAMAGE BY CALLOSOBRUCHUS MACULATUS}

The mean number of eggs laid by female $C$. maculatus was significantly $(\mathrm{P}<0.001)$ reduced among the different oil dosages compared with the control treatments (Table 2). The least number of 0.6 eggs/20g were laid on seeds treated with $1000 \mu \mathrm{l}(5.0 \%) / 20 \mathrm{~g}$ oil which was not significantly $(\mathrm{P}>0.05)$ less than number of eggs laid on the treated seeds with lower dosages. All dosages elicited over $70 \%$ reduction in oviposition in the treated seeds compared with the control (Table 2). Thus, the oil appeared to be effective in reducing the egg laying capacity of the insect pest, indicating oviposition deterrent effect.

The number of progeny produced by $C$. maculatus in untreated seeds and those treated with lower oil concentration were significantly $(\mathrm{P}<0.001)$ different (Table 3$)$. The $\mathrm{F}_{1}$ adult emergence from the control treatment 
was significantly $(\mathrm{P}<0.001)$ higher than the later. Emergence was significantly $(\mathrm{P}<0.001)$ reduced from 13.75 in the control treatment to less than 3.00 in lower dosage of oil treatments. No progeny emerged from seeds treated with $600 \mu \mathrm{l} / 20 \mathrm{~g}$ and above, indicating effective protection.

A similar observation was made on the extent of seed damage by $C$. maculatus in the oil treated seeds. There were significant $(\mathrm{P}<0.001)$ differences in the reduction of seed damage by the insect at lower dosages compared with the control (Table 3). There was no damage recorded in the seeds treated with $600 \mu \mathrm{l} / 20 \mathrm{~g}$ and above. The level of seed damage $(6.100 \pm 0.665)$ in the untreated seeds was significantly $(\mathrm{P}<0.001)$ higher than the lower dosage applications (200 and $400 \mu \mathrm{l} / 20 \mathrm{~g}$, respectively). The oil treatments, irrespective of dosage, proved superior to control and showed significant protectant potential in storage.

Table 2: Oviposition deterrent activity of $P$. guineense seed oil against $C$. maculatus

\begin{tabular}{|c|c|c|}
\hline Dosage $(\mu \mathrm{l} / 20 \mathrm{~g})($ Conc. $\%)$ & No. of $C$. maculatus eggs & \% Reduction in oviposition \\
\hline Control $(0.0 \%)$ & $32.325 \pm 3.529 \mathrm{a}$ & - \\
\hline $200(1.0 \%)$ & $7.175 \pm 1.927 \mathrm{~b}$ & 77.80 \\
\hline $400(2.0 \%)$ & $5.175 \pm 0.512 \mathrm{bc}$ & 84.00 \\
\hline $600(3.0 \%)$ & $3.500 \pm 0.576 \mathrm{bcd}$ & 89.17 \\
\hline $800(4.0 \%)$ & $1.850 \pm 0.352 \mathrm{bcde}$ & 94.28 \\
\hline $1000(5.0 \%)$ & $0.600 \pm 0.170 \mathrm{bcde}$ & 98.14 \\
\hline
\end{tabular}

Means \pm SE followed by different letters are significantly different at the 0.05 level.

Number of eggs laid was significant at $\mathrm{P}<0.001$ by Fisher's F-test.

SE: standard error.

Table 3: Production of $\mathrm{F}_{1}$ progeny and seed damage by C. maculatus on oil treated seeds

\begin{tabular}{|c|c|c|}
\hline Dosage $(\mu \mathrm{l} / 20 \mathrm{~g})($ Conc. \%) & No. of $\mathrm{F}_{\mathrm{I}}$ progeny & $\%$ damage \\
\hline Control $(0.0 \%)$ & $13.750 \pm 1.109 \mathrm{a}$ & $6.100 \pm 0.665 \mathrm{a}$ \\
\hline $200(1.0 \%)$ & $3.000 \pm 1.780 \mathrm{~b}$ & $1.525 \pm 0.909 \mathrm{~b}$ \\
\hline $400(2.0 \%)$ & $0.750 \pm 0.479 \mathrm{bc}$ & $0.625 \pm 0.361 \mathrm{bc}$ \\
\hline $600(3.0 \%)$ & $0.000 \pm 0.000 \mathrm{c}$ & $0.000 \pm 0000 \mathrm{c}$ \\
\hline $800(4.0 \%)$ & $0.000 \pm 0.000 \mathrm{c}$ & $0.000 \pm 0.000 \mathrm{c}$ \\
\hline $1000(5.0 \%)$ & $0.000 \pm 0.000 \mathrm{c}$ & $0.000 \pm 0.000 \mathrm{c}$ \\
\hline
\end{tabular}

Means \pm SE followed by different letters are significantly different at the 0.05 level.

All indices were significant at $\mathrm{P}<0.001$ by Fisher's F-test.

SE: standard error.

\subsection{EFFECT ON SEED GERMINATION}

There was no adverse effect of the oil on seed viability compared with the control treatment (Table 4). The highest germination percentage (85\%) was recorded in the seeds treated with $1000 \mu \mathrm{l} / 20 \mathrm{~g}$ seed oil. This was then followed by 800,600 and $400 \mu \mathrm{l} / 20 \mathrm{~g}$ oil treatments, which achieved $75.00,62.50$ and 50.00 percent germination, respectively.

Table 4: Effect of P. guineense seed oil on germination of cowpea seeds

\begin{tabular}{|c|c|}
\hline Dosage $(\mu \mathrm{l} / 20 \mathrm{~g})(\mathrm{conc} . \%)$ & $\%$ germination \\
\hline Control $(0.0 \%)$ & $10.00 \pm 4.10 \mathrm{a}$ \\
\hline $200(1.0 \%)$ & $25.00 \pm 6.50 \mathrm{ab}$ \\
\hline $400(2.0 \%)$ & $50.00 \pm 4.10 \mathrm{c}$ \\
\hline $600(3.0 \%)$ & $62.50 \pm 6.30 \mathrm{~cd}$ \\
\hline $800(4.0 \%)$ & $75.00 \pm 8.70 \mathrm{de}$ \\
\hline $1000(5.0 \%)$ & $85.00 \pm 2.90 \mathrm{e}$ \\
\hline
\end{tabular}

Means \pm SE followed by different letters are significantly different at the 0.05 level. 
Insecticidal Activity of Piper Guineense (Schumach And Thonn) Seed Oil Against Callosobruchus Maculatus (F.) (Coleoptera: Chrysomelidae) in Stored Cowpea Seeds

All indices were significant at $\mathrm{P}<0.001$ by Fisher's F-test.

SE: standard error.

\section{DISCUSSION}

Storage insect pest infestation results in seed weight loss, quality deterioration and low market value of cowpea. Effective control of stored product pests is very important for sustainable food supply for the teeming world population and sustainable economic growth. The use of plant extracts as alternative to synthetic insecticides has generated renewed interest in entomological research. Seed oils are commonly used in insect pest control due to their effectiveness against virtually all life stages of insects (Adedire 2002).

Efficacy of any grain protectant is attributed to its ability to induce mortality of adult and/or immature stages of pests, confirmed by lack of progeny generation and seed perforation. In this study, P. guineense seed oil demonstrated high toxicity to the cowpea bruchid and adult mortality increased as the concentration of oil increased. The 100\% mortality recorded at higher dosage applications indicated potential for $P$. guineense seed oil against storage insect pests. However, the precise mode of action for the bioactivity of the P. guineense seed oil against bruchid is not very clear. The toxic effect could result from contact action as evidenced by inability of the insects to right themselves, motionlessness after gentle touch with dissecting pin, and interference by blockage of spiracles of the insects, resulting in asphyxiation and subsequent death. Moreover, insecticidal property of any plant material would depend on the active constituents of the plant material. The potency of $P$. guineense has been attributed to piperine, the main active principle in the edible seed, which acts as a neurotoxin in insects (Scott et al. 2008). In addition, bioactivity of most insecticidal-active plant extracts is often associated with the volatile phytochemical compositions such as phenols, alkaloids, flavonoids and terpenes, which penetrate into insects and interfere with physiological functions (Rubabura et al. 2014).

The ability of $C$. maculatus to oviposit on oil treated cowpea seeds was impaired. Reduction in oviposition increased with the increase in dosage of each treatment. However, all the oil treatment levels showed high oviposition deterrent on cowpea seeds, irrespective of dosage, compared with the untreated seeds. The oil may have induced physiological and behavioral changes in the insects, thereby lowering their oviposition potential. It is also possible that the P. guineense seed oil may have affected the bruchid locomotion which led to inability of insects to mate freely. Similar oviposition suppression were reported for neem seed oil (Azadirachta indica); Nutmeg oil (Myristica fragrans), sandbox seed oil (Hura crepitans), Jatropha seed oil (Jatropha curcas) and melon seed oil (Citrullus colocynthis) (Lale and Mustapha 2000; Adedire 2002; Adedire and Ajayi 2003; Boateng and Kusi 2008; Nzelu and Okonkwo 2016). Furthermore, the black pepper oil effectively reduced the emergence of $C$. maculatus. The reduction and/or complete inhibition of $F_{1}$ emergence could be attributed to the fewer number of eggs laid, and probably the inability of the eggs to hatch. This observation implies that $P$. guineense seed oil offer a good storage treatment against $C$. maculatus. Some studies have also shown that plant-derived extracts such as Zanthoxylum zanthoxyloides, Azadirachta indica, Chenopodiu ambrosioides, Ocimum kenyense, Capsicum frutescens and Citrullus colocynthis inhibit/suppress $\mathrm{F}_{1}$ progeny emergence in insects (Obeng-Ofori et al. 1997; Ogunwolu et al. 1998; Tapondjou et al. 2002; Govindan and Jeyarajan 2008; Ileke et al. 2013; Nzelu and Okonkwo 2016). In addition, pulverized plant material from $P$. guineense was reported to inhibit egg hatchability and adult emergence of Dermestes maculatus in smoked catfish (Clarias gariepinus) during storage (Fasakin and Aberejo 2002).

Grain damage to the embryo by the feeding bruchids impairs germination and poor grain quality for human consumption due to reduction in the amounts of carbohydrates and proteins (Allotey and Oyewo 1993; Rahma and Talukder 2006). Interestingly, in this study, the inhibition of progeny emergence was strongly related to the $P$. guineense seed oil, with $100 \%$ seed protection. P. guineense seed oil did not affect cowpea seed viability and quality, even at higher concentrations. This result is consistent with previous studies with $P$. guineense seed powder (Asawalam and Emosairue 2006) and other plant products: Jatropha curcas powder (Umar 2008), Ocimum suave leaf oil (Ojianwuna et al. 2014) and Citrullus colocynthis melon seed oil (Nzelu and Okonkwo 2016) which reported that plant-derived products generally do not affect the viability of stored cowpea or maize seeds. 


\section{CONCLUSION}

This study has demonstrated the insecticidal, ovicidal and behaviour-modifying properties of $P$. guineense seed oil against $C$. maculatus in stored cowpea seeds. The seed oil did not adversely affect cowpea seed viability. These observations indicate the enormous potential for the use of edible P. guineense seed oil as protectant against stored product insect pests. It can be locally sourced and is cheap. Thus, its application as grain protectant would offer safer alternative to synthetic insecticides, especially at small-scale farmers level.

\section{SOURCES OF FUNDING}

This research received no specific grant from any funding agency in the public, commercial, or not-for-profit sectors.

\section{CONFLICT OF INTEREST}

The author have declared that no competing interests exist.

\section{ACKNOWLEDGMENT}

None.

\section{REFERENCES}

[1] Abbott, W.S. 1925. A method of computing the effectiveness of an insecticide. Journal of Economic Entomology 18 (2): 265-267.

[2] Adedire, C.0. 2002. Use of nutmeg Myristica fragrans (Houtt.) powder and oil for the control of cowpea storage bruchid, Callosobruchus maculatus Fabricius. Journal of Plant Diseases and Protection 109 (2): 193199.

[3] Adedire, C.O. and Ajayi, O.E. 2003. Potential of sandbox, Hura crepitans L. seed oil for protection of cowpea seeds from Callosobruchus maculatus Fabricius (Coleoptera: Bruchidae) infestation. Journal of Plant Diseases and Protection 110 (6): 602-610.

[4] Adedire, C.O., Obembe, O.0., Akinkurolele, R.O. and Oduleye, 0. 2011. Response of Callosobruchus maculatus (Coleoptera: Chysomelidae: Bruchidae) to extracts of cashew kernels. Journal of Plant Diseases and Protection $118(2): 75-79$.

[5] Allotey, J. and Oyewo, A. 1993. Some aspects of the biology and control of C. maculatus (F.) on some stored soybean, Glycine max (L.) Merr, varieties under tropical conditions. Proceedings of Ghana Science Association 26: 14-18.

[6] Asawalam, E.F. and Emosairue, S.0. 2006. Comparative efficacy of pepper Piper guineense (Schum and Thonn) powder and pirimiphos-methyl dust against Sitophilus zeamais Motsch (Coleoptera: Curucionidae) in stored maize. Nigerian Journal of Entomology 23: 30-33

[7] Benson, G.A.S., Joda, A.O. Sosanya, O.S. and Tokoya, B.O. 2019. Evaluation of Piper guineense in the control of cowpea storage weevils: implication for sustainable credit advancement. Agricultural Sciences 10: 530-537.

[8] Besong, E.E., Balogun, M.E., Djobissie, S.F.A., Mbamalu, O.S. and Obimma, J.N. 2016. A review of Piper guineense (African black pepper). International Journal of Pharmacy and Pharmaceutical Research 6 (1): 368-384.

[9] Boateng, B.A. and Kusi, F. 2008. Toxicity of Jatropha seed oil to Callosobruchus maculatus (Coleoptera: Bruchidae) and its parasitoid, Dinarmus basalis (Hymenoptera: Pteromalidae). Journal of Applied Science Research 4 (8): 945-951.

[10] Deshpande, V.K., Makanur, B., Deshpande, S.K., Sateesh, A. and Salimath, P.M. 2011. Quantitative and qualitative losses caused by Callosobruchus maculatus in cowpea during seed storage. Plant Archives 11 (2): 723-731.

[11] Echo, I.A., Osuagwu, A.N., Agbor, R.B. Okpako, E.C. and Ekanem, B.E. 2012. Phytochemical composition of Aframomun melegueta and Piper guineense seeds. World Journal of Applied Environmental Chemistry 2 (1): 17-21. 
Insecticidal Activity of Piper Guineense (Schumach And Thonn) Seed Oil Against Callosobruchus Maculatus (F.) (Coleoptera: Chrysomelidae) in Stored Cowpea Seeds

[12] Emeasor, K.C., Uwalaka, O.A. and Nnaji, M.C. 2017. Use of plant-derived insecticides for the control of Podagrica spp. of Abelmoschus esculentus (L.) in southeastern Nigeria. International Journal of Advance Agricultural Research 5: 95-100.

[13] Fasakin, E.A. and Aberejo, B.A. 2002. Effect of some pulverized plant materials on the developmental stages of fish beetle, Dermestes maculatus Degeer in smoked catfish (Clarias gariepinus) during storage. Bioresource Technology 85(2): 173-177.

[14] Govindan, K. and Jeyarajan, N.S. 2008. Effect of ten plant powders on mortality, oviposition, adult emergence and seed weight loss on pulse beetle, Callosobruchus maculatus (F.) (Coleoptera: Bruchidae). Hexapoda 15: 64-66.

[15] Ibekwe, H.N., Ogbu, J.U., Uwalaka, O.A., Ngbede, S.O. and Onyegbule, U.N. 2014. Efficacy of plant derived insecticides for control of insect pests of garden egg (Solanum spp.) in southern Nigeria. International Journal of Scientific Technology Research 3(8) 371-376.

[16] Ileke, K., Odeyemi, O. and Ashamo, M. 2012. Insecticidal activity of alstonia booni de wild powder against cowpea bruchid, Callosobruchus maculatus (Fab.) (Coleoptera: Chrysomelidae) in stored cowpea seeds. International Journal of Biology 4 (2): 125-131.

[17] Ileke, K.D., Bulus, D.S. and Aladegoroye, AY. 2013. Effects of three medicinal plant products on survival, oviposition and progeny development of cowpea bruchid, Callosobruchus maculatus (Fab.) (Coleoptera: Chrysomelidae) infesting cowpea seeds in storage. Jordan Journal of Biological Sciences 6(1): 61-66.

[18] Jayakumar, M. 2010. Oviposition deterrent and adult emergence activities of some plant aqueous extracts against Callosobruchus maculatus F. (Coleoptera: Bruchidae). Journal of Biopesticides 3 (1): 325-329.

[19] Lale, N.E.S. and Mustapha, A. 2000. Efficacy and acceptability of neem (Azadirachta indica A. Juss) seed oil and pirimiphos-methyl applied in three storage devices for the control of Callosobruchus maculatus (F.) (Coleoptera: Bruchidae). Journal of Plant Diseases and Protection 107(4): 399-405.

[20] Langyintuo, A.S., Lowenberg, J., Faye, M., Lambert, D., Ibro, G. and Moussa, B. 2003. Cowpea supply and demand in West and Central Africa. Field crops Research 82: 215- 231.

[21] Memudu, A.E, Akinrinade, I.D., Ogundele, O.M. and Dare, B.J. 2015. Effects of crude extract of dry fruits of Piper guineense on male fertility parameters of adult Sprague Dawley rats. European Journal of Medicinal Plants 5 (3): 297-303.

[22] Murdock, L.L., Seck, D., Ntoukam, G., Kitch, L., Shade, R.E. 2003. Preservation of cowpea grain in sub-Saharan Africa- Bean/Cowpea CRSP contributions. Field Crop Research 82 (2- 3):169-178.

[23] Nwankwo, C.S., Ebenezer, I.A., Ikpeama, A.I. and Asuzu, F.0. 2014. The Nutritional and anti-nutritional values of two culinary herbs - Uziza Leaf (Piper guineense) and Scent Leaf (Ocimum gratissium) popularly used in Nigeria. International Journal Science and Engineering Research 5 (12): 1160-1163.

[24] Nzelu, C.O. and Okonkwo, N.J. 2016. Evaluation of melon seed oil Citrullus colocynthis (L.) Schrad, for the protection of cowpea Vigna unguiculata seeds against Callosobruchus maculatus (Fabricius) (Coleoptera: Bruchidae). International Advanced Research Journal in Science, Engineering and Technology 3 (8): 76-80.

[25] Obeng-Ofori, D., Reichmuth, C.H., Bekele, J. and Hassanali, A. 1997. Biological activity of 1,8 Cineole, a major component of essential oil of Ocimum kenyense (Ayobangira) against stored product beetles. Journal of Applied Entomology 121: 237-243.

[26] Ogunwolu, E.O., Igoli, J.O. and Longs, N.N. 1998. Reduction in reproductive fitness of Callosobruchus maculatus F. exposed to Zanthoxylum zanthoxyloides (Lam.) Waterm (J.). Journal of Herbs, Spices and Medicinal Plants 6: $19-27$.

[27] Ojianwuna, C. C., Umoru, P.A. and Ugbebor, J. 2014. Toxicity of crude extracts of Ocimum suave leaf oil on cowpea weevil (Callosobruchus maculatus) (F.) (Coleoptera; Bruchidae) and test of cowpea seeds' viability. Bioresource Bulletin 3: 1-5.

[28] Ojo, J.A. Olunloyo, A.A. and Akanni, E.O. 2013. Efficacy of Moringa oleifera leaf powder against Callosobruchus maculatus (F.) (Coleoptera: Chrysomelidae) on stored cowpea (Vigna unguiculata L. Walp). Researcher 5 (12): 240-244.

[29] Okoye, E.I. and Ebeledike, A.O. 2013. Phytochemical constituents of Piper guineense (UZIZA) and their health implications on some microorganisms. Global Research Journal of Science 2 (2): 42-46.

[30] Rahman, A. and Talukder, F.A. 2006. Bio efficacy of some plant derivatives that protect grain against the pulse beetle, Callosobruchus maculatus. Journal of Insect Science 6(3): 1-10. 
[31] Raja, N., Babu, A. and Dorn, S., Ignacimuthu S. 2001. Potential of plants for protecting stored pulse from Callosobruchus maculatus (Coleoptera: Bruchidae) infestation. Biological Agricultural and Horticulture 19 (1): 19-27.

[32] Rehn, S. and Espig, G. 1991. The cultivated plants of the tropics and subtropics. Cultivation, Economic value, Utilization, Verlag, Josef, Margraf Scientific books CTA 522 pp.

[33] Rubabura, K., Nsambu, M., Muhigwa, B., Bagalwa, M. and Bashwira, S. 2014. Evaluation in vitro activity of insect alkaloid, saponins, terpenoids or steroids extracts Capscicum frutescens L. (Solanaceae) against Antestiopsis orbitalis ghesquierei, pests of coffee trees. International Journal of Innovation and Applied Studies 8(3): 1231-1243.

[34] Scott, I.M., Jensen, H., Philogene, B.J. and Arnason, J.T. 2008. A review of Piper spp. (Piperaceae) phytochemistry, insecticidal activity and mode of action. Phytochemistry Reviews 7 (1): 65-75.

[35] Shiberu, T. 2013. In vitro evaluation of aqueous extracts of some botanicals against maize borer, Busseola fusca F. (Lepidoptera: Noctuidae). Journal of Plant Pathology and Microbiology 4 (5): 179.

[36] Tapondjou, L.A., Adler, C., Bouda, H. and Fontem, D.A. 2002. Efficacy of powder and essential oil from Chenopodium ambrosioides leaves as postharvest grain protectants against six stored product beetles. Journal of Stored Products Research 38(4): 395-402.

[37] Ukpai, O.M., Ibediungha, B.N. and Ehisianya, C.N. 2017. Potential of seed dusts of Jatropha curcas L., Thevetia peruviana (PERS.) and Piper guineense Schumach against the maize weevil, Sitophilus zeamais (Motschulsky, 1855) Coleoptera: Curulionidae) in storage of corn grain. Polish Journal Entomology 86 (3): 237-250.

[38] Umar, Y. F. 2008. Comparative potentials of leaf, Bark and wood powders of Jatropha curcas (L) as protectants of stored cowpea against Callosobruchus maculatus (F.). Savannah Journal of Agriculture 3: 86-92. 